\title{
Modeling Seawater Intrusion to Coastal Aquifers in South Coast of Laizhou Bay, China
}

\author{
Yawen Chang ${ }^{1,2}$, Bill X. Hu ${ }^{\mathbf{1 , 2 , 3}, *}$, Xue $\mathrm{Li}^{1,2}$ \\ ${ }^{1}$ School of Water Resources and Environment, China University of Geosciences (Beijing), \\ No. 29 Xueyuan Road, Haidian District, Beijing 100083, P. R. China \\ ${ }^{2}$ MOE Key Laboratory of Groundwater Circulation and Environmental Evolution, China \\ University of Geosciences (Beijing), Beijing 100083, P. R. China \\ ${ }^{3}$ Institute of Groundwater and Earth Sciences, Jinan University, Guangzhou 510632, P. R. \\ China
}

\begin{abstract}
In this study, a two-dimensional SEAWAT 2000 model is developed to simulate the seawater intrusion to coastal aquifers and brine water/fresh water interaction in the south of Laizhou Bay, Shandong Province, China and forecast the seawater intrusion and brine water/freshwater interface development in the coming years. The model profile is perpendicular to the coastal line, about $40 \mathrm{~km}$ long and $110 \mathrm{~m}$ in depth, and consists of two interfaces, freshwater-saline water interface and brine water-saline water-seawater interface. The parameters of aquifers in the SEAWAT-2000 model are calibrated by trial-error method repeatedly to fit the head and salinity measurements. Based on the historical groundwater and brine water exploration and natural precipitation condition, the prediction results indicate that equivalent freshwater head in shallow freshwater-saline water area will decrease year by year and decline $2.0 \mathrm{~m}$ in the forecasting period, caused by groundwater over-pumping for irrigating farmlands. The groundwater head in the brine-saline water area will also decrease about $1.8 \mathrm{~m}$ in forecasting period. A larger depression cone appears in the brine area, with smaller funnels in other areas. The salinity in the brine area finally drops below $105 \mathrm{~g} / \mathrm{l}$. In the meanwhile, the salinity increases in other areas, damage fresh groundwater resources.
\end{abstract}

\section{INTRODUCTION}

Excessive exploitation of groundwater, climate change, sea-level rise, variation of land use haveleaded to serious seawater intrusion to coastal aquifers (Werner et al. 2013). To meet water needs in the agriculture, lives and industry, groundwater resources have been seriously over exploited in the last several decades (Datta et al. 2009).

Physically, the seawater intrusion is a density-dependent issue (Guo et al.2002). Mathematical modeling a seawater intrusion process needs to couple groundwater flow equation with solute (salt) transport equation (Priyanka et al.2015). Some studies were focused the freshwater and seawater interaction areas. For example, Li et al. (2009) applied a density-variable numerical code, SEAWAT 2000, to simulate a submarine groundwater discharge (SGD) caused by tidally induced sea water recirculation and a terrestrial hydraulic gradient. Some other studies were on freshwater-saline or brine water areas. Xue et al. (1997) developed a three-dimensional numerical model of seawater intrusion and brine water and freshwater interaction in Longkou-Laizhou area to study the interface between freshwater and saltwater, evolution and development of the transitional zone, and evaluate seawater intrusion caused by pumping. 
The above studies focus either on fresh water-saline water interaction area or brine-saline water area, without considering both interaction areas. In this paper, a large scale of a twodimensional cross-section, perpendicular to the coastal line in the Laizhou bay, China is chosen to study the variations of both fresh water-saline water interface and brine-saline water interface with time. The cross-section is about $40 \mathrm{~km}$ in length and $110 \mathrm{~m}$ in depth. Along the $40 \mathrm{~km}$ cross section, there exist a freshwater-saline water interaction area and a brine water and saline water interaction area. The two interaction areas will influence each other.

\section{OVERVIEW OF THE STUDY AREA}

The study area is located in the south of Laizhou bay, specifically in Changyi, Weifang City, Shandong Province(Figure 1).

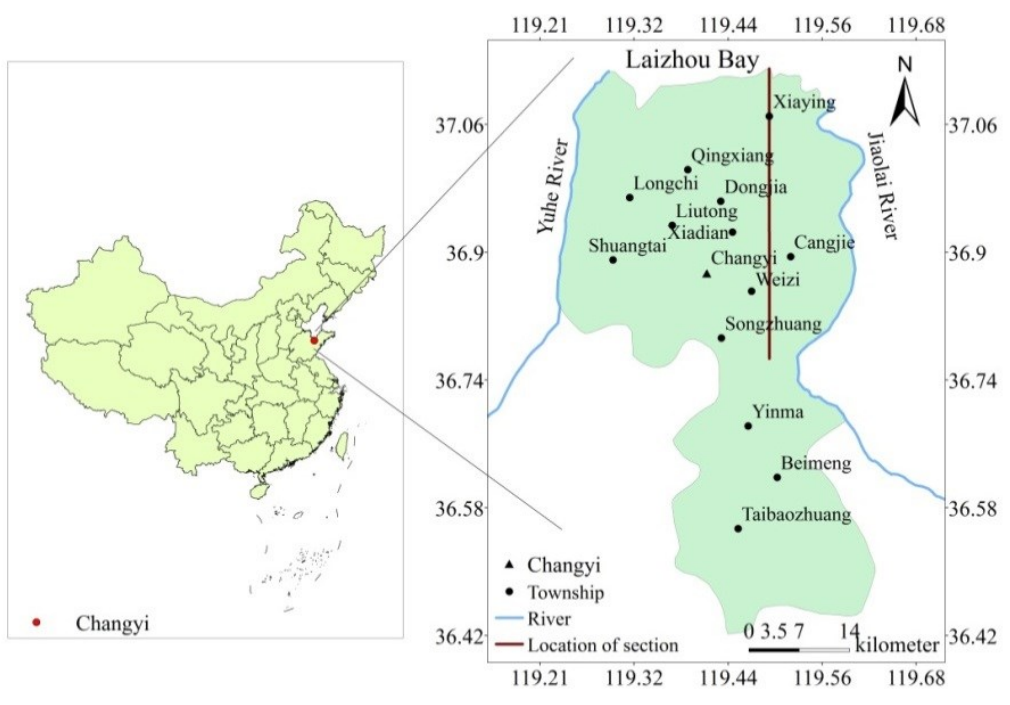

Figure 1. Geographical location of the study area.

The average annual precipitation from 1956 to 2012 is $612.5-660.1 \mathrm{~mm}$, and $72.4-76.2 \%$ of the annual precipitation is from June to September. The evaporation in April to July is relatively large. The average monthly evaporation is $191.4-371.6 \mathrm{~mm}$.

The groundwater in the Quaternary loose sediments is widely distributed in the coastal plain area. The lithology of the water-bearing sand strata is from medium coarse sands and gravels (thickness 5-30 m) to silt, fine sands and medium sands (sand thickness 10-30 m).

Since the late 1970s, due to the over exploitation of fresh groundwater, the pressure difference between salt water head and freshwater head decreased, and the brine water flowed through the ancient alluvial sand layer to the south quickly. In the Laizhou Bay coastal areas, groundwater depth in the sea-land interlaced layers is shallow and it is easy to be evaporated or to receive the supply of precipitation. So the regional water levelis closely related with weather condition and affected by seasonal change, showing a certain periodical characteristics.

\section{GROUNDWATER FLOW MODEL IN THE STUDY AREA}

According to hydrogeological conditionsin the section, the model area is ranged from Songzhuang Township-Weizi Town in the south to Xiaying Town-Wei River Estuary in the 
north. The total length is about $39200 \mathrm{~m}$ with $1000 \mathrm{~m}$ extended beyond the shoreline. The model boundaries are defined as: The south piedmont boundary of the model is a constant flow boundary with $40 \mathrm{~m}^{3} / \mathrm{d}$ since several small rivers recharge the aquifer; the north boundary extended into sea can be defined as a constant head and constant salt concentration boundary with $0 \mathrm{~m}$ and $3500 \mathrm{mg} / 1$, respectively; the bottom boundary is treated as no-flow boundary; Water exchange between the aquifer and atmosphere takes place at the upper boundary, including atmospheric precipitation and evaporation. Atmospheric precipitation and evaporation during the period from January to December, 2013 are measured by Changui weather station. The values of atmospheric precipitation recharge are products of precipitation and precipitation infiltration coefficient of 0.15 . Evaporation limit depth is $4 \mathrm{~m}$. In the freshwater-saline water area, the pumping rate of with $207,200 \mathrm{~m}^{3} /$ year are estimated according agricultural irrigation amounts for various crop requirements during the period from January to December, 2013, because the pumped groundwater is mainly used for irrigation. The pumping rate divided by the area is $0.3 \mathrm{~m}^{3} / \mathrm{m}^{2}$.year, which is used in the simulation. Brine exploitation is mainly concentrated in April, May and June with a total exploitation of 486,000 $\mathrm{m}^{3} /$ year during the period from January to December, 2013, which, divided by the area, is $0.43 \mathrm{~m}^{3} / \mathrm{m}^{2} \cdot$ year. In the freshwater-saline water area pumping rates are distributed to the grids of $0 \mathrm{~m}-27200 \mathrm{~m}$, and in the brine-saline water area pumping rates are distributed to the grids of $30600-35400 \mathrm{~m}$. The lateral recharge in the piedmont is 15,330 $\mathrm{m}^{3} /$ year. The hydraulic structure of the sediment cross-section is generated according to hydraulic properties of the sediment layers. The section is divided into 15 layers. The first, third, fifth, seventh, ninth, eleventh, thirteenth, fifteenth layer are aquifers. The lithology of the aquifers is from silt to coarse gravel. The remaining layers consist of sandy clay and clay with poor permeability, and are classified as aquitards.

In the freshwater-saline water area, the groundwater circulation in the south coast of Laizhou Bay is mainly controlled by precipitation, runoff and pumping processes. In recent years, due to the reduction of precipitation and the over-pumping, the groundwater level declines rapidly. In the brine-saline water area, the middle and deep layers in the brine funnel has a weak hydraulic connection with precipitation and shallow aquifers. The brine groundwater is mainly affected by the hydrostatic pressure and mining intensity in the recharge area.

In this paper, the mathematical model of groundwater flow with variable density is applied to simulate the seawater and brine water intrusion processes. The numerical simulation model of solute transport in groundwater flow is established using SEAWAT-2000, which couples MT3D with MODFLOW-2000, and considers the effect of density on groundwater flow.

This model consists of rectangular grid with $500 \times 100 \mathrm{~m}$. There are 392 columns and 15 layers with 5880 cells in total. The simulation period is from January 1, 2013 to December 31,2013 , and each month is taken as a stress period, and the number of days every stress period is usedas a time step. According to the lithology, the parameters areca liberated.

In general, the simulated groundwater levels and salt concentrations match the observations well. The groundwater flow field (Figure2(a)) and concentration field (Figure2(b)) could well describe the groundwater level and salinity distributions in the study area, in which there are freshwater-saline area and brine-saline water area. In freshwater-saline area, the groundwater head is relatively high, basically greater than $0 \mathrm{~m}$, and salinity is less than $20,000 \mathrm{mg} / \mathrm{l}$. Pumping groundwater occurs in shallow aquifers and the pumped water is used for irrigation. In brine-saline water area, there is depression cone with about a depth of $7.0 \mathrm{~m}$ 
below sea level, and its salinity is about $10,0000 \mathrm{mg} / \mathrm{l}$. The brine exists in the deep aquifer and the brine water is pumped for salt industry, which has been practiced for several decades.
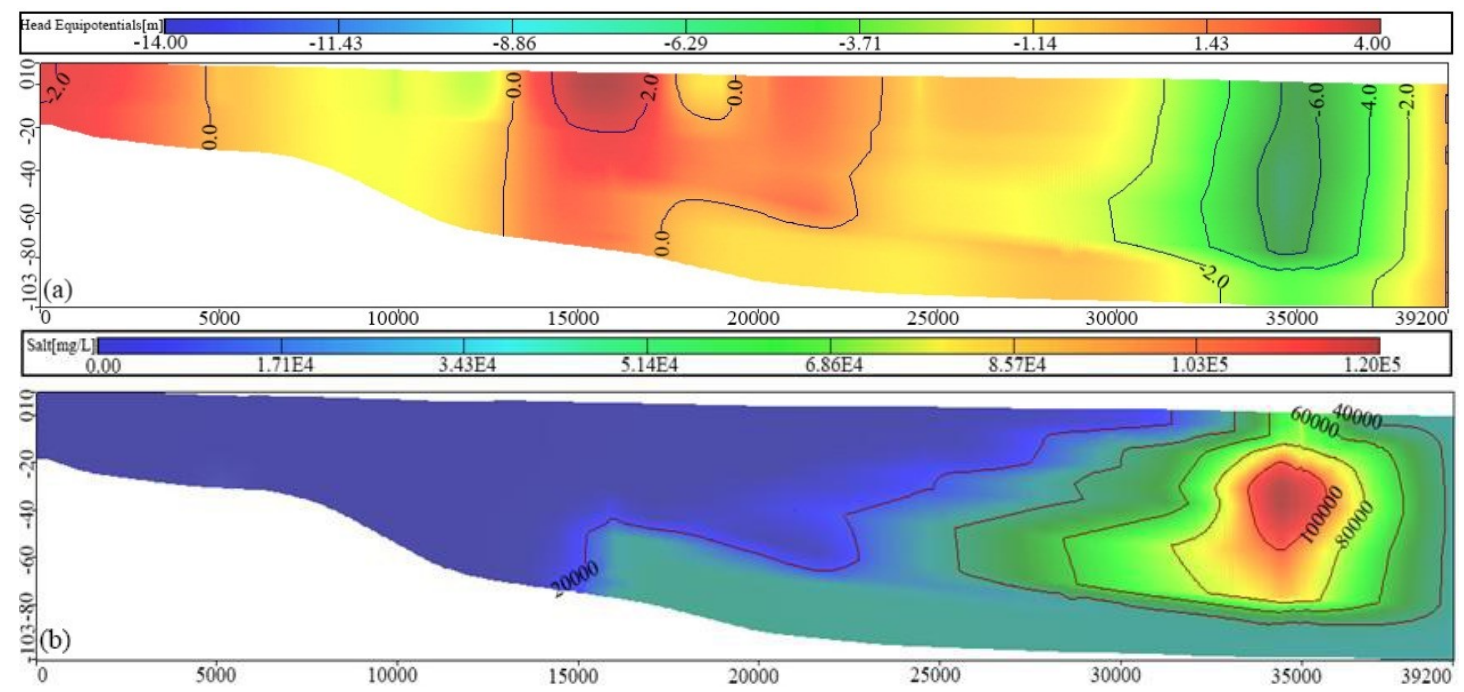

Figure 2. Groundwater flow field(a) and salinity field (b) at the end of simulation.

\section{PREDICTION RESULTS AND ANALYSIS}

The prediction simulation period for groundwater flow and solute transport in the crosssection area is 7 years (from January, 2014 to December, 2020). The rainfall has the periodicity, and the rainfall period during the period from January, 1983 to December, 1989 is a rainfall cycle, and assumed to be the cycle for the period from January, 2014 to December, 2020 in the prediction model. In the seven rainfall years, there are three consecutive dry years $(>75 \%$ cumulative frequency, rainfall $<483.1 \mathrm{~mm}$ ), which can allow our model to meet the requirements for predicting groundwater level and quality trends under special climate conditions. Also, the evaporations from 1983 to 1989 are taken as the evaporations inputs in the prediction simulation. Pumping rates from 2014 to 2020 are taken as the same as those in 2013 in the freshwater-saline water area and brine-saline water area.

In the shallow freshwater area, the groundwater level is declining year by year. In a hydrological year, the amount of groundwater pumping increases with less precipitation and more evaporation when spring irrigation season starts. Therefore, the water level declines 0.3 $\mathrm{m}$ to the lowest in June. Then, the groundwater table will rise slowly with the precipitation increase and groundwater exploitation decrease, and reach the highest level in September or October. Due to large water demand for winter wheat, the water level declines from November to February in the following year. For many years, the groundwater level will decrease year by year due to the continuous drought condition, the reduction of the precipitation recharge and the excessive exploitation of groundwater. A large hydraulic cone has formed in the coastal plain, induced seawater intrusion to the freshwater aquifer. The salinity of the shallow freshwater area increases, the main reason is that the exploitation amount of fresh water is higher than recharge, which decreases hydraulic head and increases salt water inflow into the shallow layers.

In the deep layers of funnel area, the depth of the deep water recharge zone is large, and the hydraulic head is slow to restore, the water level has been decreasing for many years. In the forecast periods, the annual variation is about $6 \mathrm{~m}$, and the mean hydraulic head decreases 
about $1.8 \mathrm{~m}$ in the next 7 years. The hydraulic gradient in the northern brine zone will increase, which would increase seawater intrusion to the groundwater. The salinity of the deep brine funnel is also reduced, mainly due to the pumping of the brine with high salinity, while the recharge of seawater with relatively low salinity or fresh water and no brine recharge will make the brine water salinity decrease.

\section{SUMMARY AND CONCLUSIONS}

The groundwater head at the freshwater-saline water area is decreasing year by year under drought condition, and the annual variation is about $0.3 \mathrm{~m}$, and the hydraulic head decrease in the forecasting period is about $2 \mathrm{~m}$. The groundwater head in the brine mining area is also decreasing year by year, and the annual variation is about $6 \mathrm{~m}$, and the hydraulic head decrease in forecasting period is about $1.8 \mathrm{~m}$.

The salinity of the brine decreases gradually, and finally drops below $105 \mathrm{~g} / \mathrm{l}$ and the salinity of the other areas increases. The overpumping in the brine area will significantly decrease the brine salinity and deepen the brine water depth, which means the production will be less effective and cost will increase. The overpumping in the fresh water area will increase water and soil salinity, significantly affect the biological environment.

\section{ACKNOWLEDGEMENTS}

This work was partly supported National Natural Science Foundation of China (41530316) and National Key Research Project(2016YFC0402805).

\section{REFERENCES}

Datta, B., Vennalakanti, H., Dhar, A.2009. Modeling and control of saltwater intrusion in a coastal aquifer of Andhra Pradesh, India. Journal of Hydro-environment Research, no. 3:148-159.

Guo, W., Langevin, C.D.2002. User's guide to SEAWAT: a computer program for simulation of three-dimensional variable-density groundwater flow. US Geological Survey, 1-434.

Li, X.Y., Bill, X.H., Burnett, W.C., Santos, I.R., Chanton, J.P. 2009.Subarine groundwater discharge driven by tidal pumping in a heterogeneous aquifer. Ground Water, 47(4): 558-568.

Priyanka, B.N., Maheshab, A. 2015. Parametric studies on saltwater intrusion into coastal aquifers for anticipate sea level rise. Aquatic Procedia, no. 4: 103-108.

Werner, A.D., Bakker, M., Post, V.E.A., Vandenbohede,A., Lu, C.H., Ataie-Ashtianiab, B., Simmonsab, C.T., Barry, D.A. 2013. Seawater intrusion processes, investigation and management: recent advances and future challenges. Adv. WaterResour. 51 (1):3-26.

Xue, Y.Q., Wu, J.C., Xie, C.H., Zhang, Y.X. 1997. Research of seawater and salt water intrusion of Laizhou Bay. Chinese Science Bulletin,11(22):2360-2368.

Contact Information: bill.x.hu@gmail.com 